\title{
PEMBELAJARAN SENI DAN TEKNOLOGI DIGITAL SEBAGAI MEDIA BELAJAR DAN PERKEMBANGAN ANAK USIA DINI
}

\author{
Oleh \\ Ni Komang Sri Cahya Dewi ${ }^{1}$, W Wayan Suyanta ${ }^{2}$ \\ 'PAUD PRA KUMARA DHARMA KERTI LUKLUK \\ ${ }^{2}$ Dosen IHDN Denpasar \\ cahyadewi@gmail.com \\ suyanta.kaler@gmail.com
}

\begin{abstract}
The importance of the early years of a person's life has been realized by all parties because at an age of individual brain brain grows very rapidly, even the results of research states that its development reaches up to more than 50\%. Early age is a fundamental phase for the development of individuals who are also called golden age or golden age. The experiences children experience may shape the experience they will carry throughout their lives. Implications in the field of early age is necessary steps appropriate (significant and strategic) to equip the child from an early age. Efforts to be taken will be considered more strategic if associated with the assumption that the child is a future practitioner. He will fill the good or bad of tomorrow. That is, the success of fostering children from an early age is a success for the future of children. on the contrary, failure to provide coaching, education, nurturing, and treatment will be disastrous for the life of the child in the future.
\end{abstract}

\section{Keywords: Art, Digital Technology and Psychology of early childhood education programs}

\begin{abstract}
Abstrak
Pentingnya tahun-tahun awal kehidupan seseorang sudah disadari oleh semua pihak karena pada usia dinilah otak individu berkembang sangat pesat, bahkan hasil penelitian menyatakan bahwa perkembangannya mencapai hingga lebih dari $50 \%$. Usia dini adalah fase fundamental bagi perkembangan individu yang disebut juga sebagai golden age atau usia emas. Pengalaman-pengalaman yang dijalani anak mungkin akan membentuk pengalaman yang akan dibawa seumur hidupnya. Implikasinya pada bidang usia dini adalah diperlukan langkah yang tepat (signifikan dan strategis) untuk membekali anak sejak usia dini. Upaya yang akan diambil akan dianggap semakin strategis jika dikaitkan dengan anggapan bahwa anak dalah praktisi masa depan. Dialah yang akan mengisi baik atau buruknya hari esok. Artinya, keberhasilan membina anak sejak dini merupakan kesuksesan bagi masa depan anak. sebaliknya, kegagalan dalam memberikan pembinaan, pendidikan, pengasuhan, dan perlakuan akan menjadi bencana bagi kehidupan anak di masa yang akan datang.
\end{abstract}

\section{Kata Kunci: Seni, Teknologi Digital dan Psikologi perkembangan PAUD}

\section{PENDAHULUAN}

Pengertian Pembelajaran Seni Anak Usia Dini (PAUD). Pengertian Pembelajaran Seni adalah sejumlah kegiatan yang dapat dilakukan oleh anak dengan lebih banyak melibatkan kemampuan motorik, khususnya motorik halus. Pada kelompok usia 4-6 tahun pemenuhan kebutuhan anak untuk berekspresi itu mendapat bimbingan dan pembinaan secara sistematis dan berencana agar kesempatan berekspresi 
yang diberikan kepada anak benar-benar mempunyai arti dan bermanfaat baginya. Jika mulai sejak dini anak diberikan bimbingan dan pembinaan yang sebaikbaiknya untuk mengekspresikan dirinya secara kreatif dan menghayati emosi yang bergejolak dalam dirinya, maka daya fantasi atau imajinasi, daya kreasi dan perasaan estetis, anak memperoleh rangsangan untuk berkembang dengan anak. Setiap anak mempunyai keinginan untuk menciptakan sesuatu. Hasrat dan kemampuan yang ada dirangsang dan dibina sehingga memperoleh kesanggupan untuk menciptakan sesuatu dan merasa puas akan hasil ciptaannya. Rasa puas akan hasil ini merupakan dorongan bagi anak untuk ingin selalu menciptakan sesuatu yang baru yang mendorong anak menjadi lebih kreatif.

Pada masa globalisasi sekarang ini, teknologi juga berkembang sangatlah cepat. Muncul berbagai produkproduk teknologi yang sangat canggih dan memudah kehidupan manusia. Banyak manfaat yang diberikan karena kemunculan produk teknologi ini. Namun, produk teknologi ini juga memiliki bahaya dan dampak negatif yang dapat ditimbulkan apabila digunakan secara berlebihan dan tidak sesuai dengan penggunaan sewajarnya. Jika manusia tidak bisa mengendalikan diri dan orang lain dalam penggunaan produk teknologi, manusia bisa menjadi budak teknologi.

\section{Pembahasan}

Pembelajaran seni, alat digital dan psikologi perkembangan Anak Usia Dini (PAUD)

Pemberlakuan Kurikulum PAUD 2013 berimplikasi pada perlunya pengembangan pembelajaran. Guru PAUD, sebelum melaksanakan kegiatan pembelajaran perlu mempersiapkan diri. Salah satu bentuk persiapan adalah menyusun model pembelajaran yang sesuai dengan karakteristik perkembangan fisik dan psikologis anak usia dini, keadaan lingkungan sekitar dan ketersediaan sarana prasarana pendidikan.

Dari berbagai pembelajaran yang perludisusunolehguru, diantaranya adalah pembelajaran bidang pengembangan kemampuan seni. Kemampuan seni merupakan salah satu dari bidang kemampuan dasar yang dikembangkan untuk meningkatkan kreativitas anak yang bermuara ke arah pembentukan watak bangsa dan kehalusan budi.

Pembelajaran bidang seni yang dikembangkan dan diimplementasikan di sekolah tidak harus seperti contoh dalam pedoman ini. Pedoman ini dapat menjadi rujukan bagi guru dalam mengembangkan model pembelajaran. Guru dapat mengembangkan sesuai kreativitasnya, sejauh tidak bertentangan dengan prinsip dan asas pembelajaran di KB dan TK.

Berkaitan dengan pengembangan kemampuan seni bagi anak PAUD, maka pembelajaran seni merupakan sejumlah kegiatan yang dapat dilakukan oleh anak dengan lebih banyak melibatkan kemampuan motorik, khususnya motorik halus. 
Pentingnya tahun-tahun awal kehidupan seseorang sudah disadari oleh semua pihak. Pada masa globalisasi sekarang ini, teknologi juga berkembang sangatlah cepat. Muncul berbagai produk-produk teknologi yang sangat canggih dan memudah kehidupan manusia. Banyak manfaat yang diberikan karena kemunculan produk teknologi ini. Namun, produk teknologi ini juga memiliki bahaya dan dampak negatif yang dapat ditimbulkan apabila digunakan secara berlebihan dan tidak sesuai dengan penggunaan sewajarnya. Jika manusia tidak bisa mengendalikan diri dan orang lain dalam penggunaan produk teknologi, manusia bisa menjadi budak teknologi.

Produk-produk teknologi tersebut juga perlu diperkenalkan kepada anak usia dini. Banyak manfaat yang akan didapat oleh anak yang dapat memanfaatkan teknologi secara tepat. Pendidik dan orangtua bisa menstimulasi secara tepat menggunakan produk teknologi bisa jadi di masa yang akan datang anak bisa membuat produk teknologi itu sendiri. Pendidik dan orangtua harus selalu mengawasi anak agar tidak menjadi kecanduan atau menjadi budak teknologi.

1. Konsep Produk Teknologi

2. Pengertian Teknologi dan Produk Teknologi

Pengertian teknologi sebenarnya berasal dari kata Bahasa Perancis yaitu "La Teknique" yang dapat diartikan dengan "Semua proses yang dilaksanakan dalam upaya untuk mewujudkan sesuatu secara rasional"

Teknologi dalam arti ini dapat diketahui melalui barang-barang, benda- benda, atau alat-alat yang berhasil dibuat oleh manusia untuk memudahkan dan menggampangkan realisasi hidupnya di dalam dunia. Hal mana juga memperlihatkan tentang wujud dari karya cipta dan karya seni (Yunani techne) manusia selaku homo technicus. Dari sini muncullah istilah "teknologi”, yang berarti ilmu yang mempelajari tentang "techne" manusia. Tetapi pemahaman seperti itu baru memperlihatkan satu segi saja dari kandungan kata "teknologi". Teknologi sebenarnya lebih dari sekedar penciptaan barang, benda atau alat dari manusia selaku homo technicus atau homo faber. Teknologi bahkan telah menjadi suatu sistem atau struktur dalam eksistensi manusia di dalam dunia. Teknologi bukan lagi sekedar sebagai suatu hasil dari daya cipta yang ada dalam kemampuan dan keunggulan manusia, tetapi ia bahkan telah menjadi suatu "daya pencipta" yang berdiri di luar kemampuan manusia, yang pada gilirannya kemudian membentuk dan menciptakan suatu komunitas manusia yang lain.

Teknologi juga penerapan keilmuan yang mempelajari dan mengembangkan kemampuan dari suatu rekayasa dengan langkah dan teknik tertentu dalam suatu bidang. Teknologi merupakan aplikasi ilmu dan engineering untuk mengembangkan mesin dan prosedur agar memperluas dan memperbaiki kondisi manusia atau paling tidak memperbaiki efisiensi manusia pada beberapa aspek.

Kemajuan produk teknologi perlu dikenalkan pada anak. secara langsung dan tidak langsung anak akan berhadapan dengan berbagai produk teknologi. Oleh 
karena itu, pengetahuan produk teknologi menjadi sangat penting agar kelak anak dapat beradaptasi dangan berbagai macam produk teknologi, memiliki apresiasi terhadap produk teknologi, dan pada akhirnya kelak mampu mengembangkan produk teknologi.

Psikologi Perkembangan Anak adalah suatu cabang ilmu yang tujuan utamanya meneliti aspek psikologis yang terjadi selama masa kanak-kanak (dari lahir sampai dengan pubertas). Perubahan banyak sekali terjadi selama usia kurang dari lima tahun, terutama selama masa bayi, yang berlangsung dari lahir sampai dengan usia dua tahun. Ada perkembangan khusus yang menonjol pada perkembangan fisik, perkembangan kognitif, dan psikososial. semuanya adalah bidang utama penelitian dalam psikologi anak.

Psikologi anak mempunyai satu tujuan utama yaitu mempelajari bidang perilaku anak yang berbeda, sedangkan perkembangan anak mempunyai enam tujuan yaitu menemukan apa saja karakteristik perubahan usia dalam penampilan, perilaku, minat, dan tujuan dari suatu periode perkembangan ke periode yang lain. Untuk menemukan kapan perubahan ini terjadi. Untuk menemukan dalam kondisi apa saja terjadinya perubahan ini. Untuk menemukan bagaimana perubahan ini mempengaruhi perilaku anak. Untuk menemkan perubahan ini dapat diramalkan atau tidak. Dan yang terakhir untuk menemukan apakah perubahan ini sifatnya individu atau sama bagi semua anak Tokoh paling berpengaruh dalam perkembangan anak adalah Jean Piaget dengan teori perkembangan kognitifnya. Piaget seorang psikolog Swiss meyakini bahwa anak-anak belajar melalui pengalaman tangan, memiliki keberhasilan dan kegagalan, kemudian menggunakan keberhasilan dan kegagalan untuk membentuk representasi mental mereka sendiri dari dunia. Piaget juga percaya bahwa anak-anak proses belajar yang bagus dan kuat, bergerak dari satu tahap ke tahap lain setelah mereka mencapai tahap perkembangan tertentu.

Teori dari Piaget disebut Teori Pengembangan Kognitif yang terdiri dari empat tahap: sensorimotor, praoperasional, operasional konkrit, dan formal operasional.

1. Tahap sensorimotor terjadi dari Lahir sampai dengan dua tahun. Selama tahap ini anak mengenal dunia melalui indera mereka dan tindakan seperti menyentuh, melihat dsb. Ketika anak berhasil mengetahui bahwa ada benda bahkan ketika tersembunyi dari pandangan dan juga si anak tadi mengalamai rasa cemas dengan adanya orang asing, maka mereka telah berhasil menyelesaikan tahap ini dan pindah ke tahap berikutnya.

2. Tahap praoperasiona 1 terjadi dari dua tahun sampai dengan 6 tahun. Selama tahap ini, anak mampu mewakili dunia dengan kata-kata dan gambar, tapi mereka masih tidak bisa menggunakan penalaran logis yang benar.

3. Tahap operasional konkret terjadi dari tujuh tahun sampai dengan 
sebelas tahun. Selama tahap ini, anak belajar Konservasi misalnya, menuangkan cairan ke dalam gelas dengan ukuran yang berbeda tidak mengubah jumlah cairan. Dengan kata lain, mereka belajar bahwa perubahan dalam bentuk tidak berarti ada perubahan dalam kuantitas atau volume.

4. Tahap Operasional Formal terjadi dari sekitar dua belas tahun sampai dewasa. Selama tahap ini, anak belajar menggunakan penalaran abstrak. Ini adalah langkah besar sebagai penalaran sekarang melampaui beton (membutuhkan pengalaman aktual) untuk berpikir abstrak yang melibatkan simbol dan imajinasi.

\section{Konsep kelas Lysit-Art menggunakan Metode Montessori}

Metode montessori merupakan metode pembelajaran yang dibuat berdasarkan teori perkembangan dari dr. Maria Montessori. Maria Montessori merupakan seorang pendidik yang mengenalkan metode pembelajaran ini di Italia, sekitar akhir abad 19 hingga awal abad 20 .

Konsep dasar montessori adalah "follow the child." Konsep tersebut meliputi pembelajaran yang disesuaikan dengan bakat dan minat anak. Anak tidak akan mempelajari materi yang menyamaratakan kemampuannya dengan anak lain. Jika mereka memiliki bakat dan minat pada kesenian, maka pembelajaran yang diterima berkaitan dengan kesenian pula.
Konsep "follow the child" pada montessori bertujuan untuk memaksimalkan potensi anak pada bidang yang digemarinya. Hal ini tentu berbeda dengan konsep pembelajaran konvensional yang menuntut anak untuk memiliki kemampuan di segala bidang. Padahal belum tentu anak tersebut berminat dan tertarik.

Jika anak tidak tertarik, hal tersebut tentu berakibat pada kemampuan akademisnya. Anak akan dinilai dan diberi cap pemalas, tidak pintar, atau bahkan bodoh. Padahal kesalahan bukan pada anak, tetapi pada sistem yang menuntut mereka untuk mampu dalam segala hal walaupun belum tentu bakat mereka ada pada hal-hal tersebut.

Inilah yang membuat sistem pembelajaran konvensional dinilai tidak efisien dan efektif. Selain mampu memaksimalkan potensi anak, metode montessori juga memiliki beberapa manfaat bagi pendidikan mereka. Berikut ini merupakan 5 manfaat metode montessori untuk anak usia dini:

1. Anak menjadi lebih mandiri

Anak usia dini yang dididik dengan metode montessori akan tumbuh menjadi pribadi mandiri dan tidak bergantung pada orang lain. Hal ini karena pada kurikulum montessori terdapat satu poin yang diberi nama metode practical life. Pada metode ini, anak usia dini dilatih untuk menyelesaikan tugas seharihari tanpa bantuan orang dewasa. Materi dalam metode practical life mencakup: berlatih mengikat tali sepatu, menyiapkan makan dan 
minum, hingga mandi sendiri tanpa dibantu orang tua.

2. Mampu mengasah kemampuan motorik

Pada anak usia dini, terutama mereka yang berumur 4 tahun. Metode montessori yang diberikan bertujuan untuk mempertajam dan melatih saraf motorik, baik itu motorik halus maupun kasar. Hal inilah yang membuat anak-anak montessori memiliki kemampuan motorik yang baik dibanding dengan mereka yang dididik dengan metode pembelajaran konvensional

3. Anak menjadi lebih kritis

Materi-materi yang diberikan pada metode pembelajaran montessori membuat anak terbiasa mencari solusi dari masalah yang timbul. Meskipun masalah tersebut berupa permainan sederhana, tetapi hal tersebut mampu melatih jiwa kritis dalam diri mereka. Jalan pikiran anak-anak montessori pun menjadi lebih terbuka dibanding dengan anak seusianya.

4. Anak menjadi lebih kreatif

Metode montessori memang dikenal lebih bebas dan terbuka daripada metode pendidikan konvensional. Materi-materi pada metode montessori diciptakan agar anak mampu memiliki kreativitas. Hal ini juga didukung orang tua montessori yang tidak terlalu membatasi ruang gerak anak saat belajar dan bermain. Meskipun bebas, metode montessori menuntut orang tua untuk selalu mendampingi anak agar kebebasan mereka terarah. Anak-anak yang dibiarkan memiliki ruang gerak dan imajinasi tidak terbatas akan tumbuh menjadi pribadi yang kreatif dalam segala hal, termasuk soal menghadapi kehidupan ketika mereka dewasa nanti.

5. Anak mampu bersosialisasi dengan baik

Kecerdasan seorang anak tidak selalu dinilai dari kemampuan akademisnya saja, tetapi juga cara mereka bersosialisasi. Anak-anak yang dididik menggunakan metode montessori, biasanya lebih cepat berbaur dengan lingkungan sekitar, pandai bekerja sama, dan memiliki sikap toleransi yang tinggi.

\section{Rumah Bermain}

Warung Mina Dalung yang bertempat di Jalan Raya Padang Luwih No. 118 Kuta Utara pada hari Sabtu, 17 Februari 2017 mendapat kunjungan anak-anak dari TK Kumara Dharma Kerti Lukluk sebanyak 25 anak. Kunjungan anak-anak ini untuk bermain dan belajar. TK Dharma Kumara Kerti Lukluk bekerja sama dengan pihak swasta yakni Warung Mina Dalung menyelenggarakan kegiatan di luar sekolah setiap 2 minggu sekali.

Sebelum kegiatan dimulai, kedatangan anak-anak disambut oleh .... selaku Manager Warung Mina Dalung.

Tujuan kegiatan ini untuk mengenalkan Lysit Art dan dunia perikanan kepada anak-anak di usia dini. 
Dalam kegiatan kunjungan, anakanak TK Kumara Dharma Kerti Lukluk diajak mendongeng Men Sugih Ajak Men Tiwas yang dibawakan oleh Kak Made dan Kak Wayan, anak-anak begitu sangat antusias dalam mendengarkan dongeng karena disajikan dengan menarik dan inspiratif. Setelah kegiatan mendongeng, dilanjutkan dengan kegiatan mewarnai 3 dimensi dibawakan oleh Kak Wahyu dan temen-temannya dalam kelas LysitArt. Kegiatan mewarnai 3 dimensi disajikan dengan teknologi digital yang sangat canggih sehingga hasil siswa bisa discan dan muncul diprojektor, gambar tersebut bisa bergerak. Tetapi tidak semua gambar bisa digerakkan, hanya gambar yang rapi. Disamping itu, kesabaran dan ketelitian anak-anak dilatih dalam kegiatan mewarnai. Dalam kelas Lysit-art menggabungkan antara seni, teknologi digital dan psikologi perkembangan anak memalui metode mentossorik yang tepat maka, pembelajaran akan menjadi menyenangkan dan bermanfaat. Selanjutnya anak-anak diperkenalkan tentang cara mengolah makanan yang berbahan baku dari ikan. Di Rumah Bermain, anak-anak dikenalkan cara dan mengolah ikan dan dalam bentuk pizza. Setelah membuta pizza, anak-anak makan bersama dengan hasil pizza yang mereka buat.

Kegiatan ini sangat bermanfaat, disamping mengenalkan Rumah Bermain, anak-anak juga mempelajari dan mengembangkan kemampuan dari suatu rekayasa dengan langkah dan teknik tertentu dalam suatu bidang.
Kedepan kegiatan seperti ini akan lebih dikembangkan lagi, sebagimana perkembangan arus global.

Dimana pihak swasta yakni Warung Mina Dalung yang mensponsori tempat/ rumah bermain, setiap Lembaga PAUD di Lingkungan Kabupaten Badung diizinkan menyelenggarakan kegiatan rumah bermain, kerja sama pihak swasta yang mendukung program PAUD, merupakan kepedulian pengusaha terhadap Anak Usia Dini.

\section{SIMPULAN}

Pada kelompok usia 4-6 tahun pemenuhan kebutuhan anak untuk berekspresi itu mendapat bimbingan dan pembinaan secara sistematis dan berencana agar kesempatan berekspresi yang diberikan kepada anak benar-benar mempunyai arti dan bermanfaat baginya. Jika mulai sejak dini anak diberikan bimbingan dan pembinaan yang sebaikbaiknya untuk mengekspresikan dirinya secara kreatif dan menghayati emosi yang bergejolak dalam dirinya, maka daya fantasi atau imajinasi, daya kreasi dan perasaan estetis, anak memperoleh rangsangan untuk berkembang dengan anak. Setiap anak mempunyai keinginan untuk menciptakan sesuatu. Hasrat dan kemampuan yang ada dirangsang dan dibina sehingga memperoleh kesanggupan untuk menciptakan sesuatu dan merasa puas akan hasil ciptaannya. Rasa puas akan hasil ini merupakan dorongan bagi anak untuk ingin selalu menciptakan sesuatu yang baru yang mendorong anak menjadi lebih kreatif. Di era globalisasi saat ini, teknologi 
berkembang dengan pesat dan anakanak sudah mulai mengenal serta ikut mengoperasikannya. Kemajuan produk teknologi perlu dikenalkan pada anak. secara langsung dan tidak langsung anak akan berhadapan dengan berbagai produk teknologi. Oleh karena itu, pengetahuan produk teknologi menjadi sangat penting agar kelak anak dapat beradaptasi dangan berbagai macam produk teknologi, memiliki apresiasi terhadap produk teknologi, dan pada akhirnya kelak mampu mengembangkan produk teknologi.

\section{DAFTAR PUSTAKA}

1. https://www.paud.id/2015/09/ pengertian-pembelajaran-senianak-usia-dini.html

2. https://babydanbunda.wordpress. com/2014/01/17/psikologiperkembangan-anak/commentpage- $1 /$

3. https://paud-anakbermainbelajar. blogspot.co.id/2014/01/ perkembangan - teknologi permainan-anak.html

4. https://id.theasianparent.com/ metode-montessori-paud/ 